\title{
IMPORTANCE AND APPLICATION OF MARKETING IN SMALL ANIMAL PRACTICE
}

\author{
V. Vidić, S.Savić, B.Vidić, Ž.Grgić \\ Scientific Veterinary Institute "Novi Sad", Novi Sad, Republic of Serbia \\ Corresponding autor: vaso@niv.ns.ac.rs \\ Communication
}

\begin{abstract}
The main goals of marketing are the following: firstly, to attract new customers by emphasizing the potential value of the product or service offered and secondly, to keep the existing customers by keeping them satisfied with the product or service by constantly producing superior value and exceeding their expectations. Contrary to the U.S.A., where greatest achievements were accomplished in the field of marketing theory and application and its implementation into veterinary practice, as well as in appropriate perception of importance of marketing idea and philosophy, this issue has not been appropriately addressed in our country. The main goal of marketing in veterinary practice is not only to sell a product or service, but also to create mutual profitable long-term relations with clients. Disregarding personal reasons for practicing veterinary medicine, particularly in small-animal practice, the veterinarian should approach such practice as any other business activity that should provide profits. In that respect, it is of key importance to adopt marketing approach and management concept. The four basic marketing instruments are product, price, promotion and place that make so-called marketing mix, which is applicable also in the veterinary practice. In veterinary medicine, the product pertains to spent items (e.g. drugs, food) or veterinary services. By determining the price, the basis is the cost price and added profit margin, depending on the product or service offered. The promotion encompasses communication with the owners, presenting them products and services offered, describing the features of the clinic or infirmary, etc. Contrary to other business branches, position of veterinary unit is not so important, yet it must provide good communication with animal owner. The overall experience of the customer, starting from entering the clinic / infirmary until leaving it, must be professional, pleasant and effective. Only accomplishing this goal will enable competitiveness or justify even a higher price for a superior service.
\end{abstract}

Key words: marketing, marketing mix, veterinary services 


\section{Introduction}

Marketing as a term has developed from an English word "market". Most of the people would say that marketing is advertizing or selling, but marketing is made out of quite a lot of different procedures then the two named ones. There is no consent about the unique definition of marketing, not even in the literature. Definition of American Marketing Association states that marketing is an activity and set of processes for creation, communication, distribution and trade of products and services, which have a value for the buyers, clients, partners and society as a whole (23).

Pride and Ferell (Pride and Ferell, 2010) state that marketing is a process of creation, distribution, promotion and determination of product and service prices, what facilitates satisfying the client, develops and maintains satisfactory relation with all interest groups in the changing environment. Clients expect to benefit in exchange for the price that they pay in the transaction, while a company expects to profit from a price charged (Pride and Ferell, 2010). The aim of marketing, according to Kotler, is to build mutually profitable long lasting relations with the clients, and not only to sell the product or a service. This requires from a marketing managers to know their clients good enough so that they can make an appropriate offer of products and services, which meet their demands (Kotlter, 2003). Kotler defines marketing as a professional function that identifies unfulfilled wishes and needs, defines and measures their size and potential profitability, determines which target markets an organization can serve the best, decides about certain products and services which will be out in the market and invites everybody in the organization to be pointing to satisfying the client (Kotlter, 2003). This definition includes all aspects of marketing and determines it in the best way.

Two basic objectives of marketing are: attracting new customers by highlighting the potential value of the product or service offered and keeping the existing clients by constantly meeting and exceeding their expectations with a product or service (Moore and Pareek, 2010). In modern business, the second demand demonstrated greater significance compared to the first one. The research has shown that attracting new clients can be more expensive then retaining the existing ones. Moreover, exceeding the expectations of the client is the key point of this strategy. It is no longer enough "just" to satisfy the clients, they have to be delighted, because that is the only sound way how to get to the loyal customer, what is certainly the most valuable asset of every company.

Although marketing as a scientific and teaching discipline has emerged recently, i.e. in 1905 at the University of Pennsylvania, the history of marketing is much longer in the practice. Kotler quotes an opinion of Drucker that the concept of marketing was accepted for the first time in $17^{\text {th }}$ century in Japan, when family 
Mitsu opened something that could be named a first department store (Kotler, 1988). The evolution of marketing encompasses three phases (Pride and Ferell, 2010):

1) Product Orientation: in the second half of XIX century, the industrial revolution was at its full speed and the demand was way over the offer, so the aim was only to produce as much as possible and satisfy that demand.

2) Sales Orientation: from 1920 until the beginning of 1950, the offer of products has been growing while the demand was reduced, which was primarily due to the Great Depression. Because of this, the efforts for selling were growing and the most important marketing activities were personal sales, advertizing and distribution.

3) Marketing Orientation: it has been noticed that the promotion itself cannot do much, wishes and demands of customers had to be revealed and such products must be produced. Up to that time, the products were produced before thinking what would be done with them, which was not a good way of working. A customer is not an opponent, it is necessary to keep him by fulfilling his wishes and working on long-term relations. All employees at the company have to think in a good marketing way, regardless the job they are doing, since satisfied customer is the most important goal for all of them.

The history of marketing in veterinary practice is not very long (Međugorac, 2009; Vidić, 2012a). The development of marketing in veterinary practice was significantly supported by the articles published in the journal Veterinary Economics and numerous books published mostly in the U.S. (Ackermann, 2007). These articles and books address all issues relevant for veterinary practice, from the moment of taking decision to establish a practice and the best way to do it, everyday activities in the practice and adjusting to variable working environment to making decision to sell the practice. In Serbia, marketing in veterinary practice has been rarely discussed issue among professionals (Vidić, $2012 b$ ). Since recently, veterinary practice has been considered a business requiring high quality of service since strong competition imposes the necessity of using marketing tools in order to achieve competitive advantage, survive and grow in the market (Boboš et al., 2013, Vidić et al.2007, Vidić et al.2011b).

\section{Marketing Mix in veterinary practice}

Marketing mix is a combination of instruments used by the organization or a company in accomplishing its goals. Marketing mix is one of the main concepts in marketing and the main instruments are product, price, place and promotion (Vasiljev, 2005). Marketing mix is often referred to as a "strategy 4P" because of the first letters of English words for the four instruments: product, price, place, promotion (Tadić, 2011). Each of these marketing mix instruments is a variable 
manipulated by managers in order to achieve company's goals. A synergy effect produced by combining these instruments in the right way is also very important. Of course, this strategy can be used only if the operating costs are lower than the effects. The company aims to find out a combination of instruments to provide maximum difference between the effect and cost.

In the book "Business basic for veterinarians", Ackerman states that the instruments of marketing mix can be successfully applied in veterinary practice; however, with taking into consideration the specificities of this practice (Ackerman, 2002). In veterinary practice, a "product" can be an expendable product such as feed for pets or medicines, or veterinary service. It is very important to regard the product as a value delivered to the client and his/her pet and not as a physical entity or service. In managing the veterinary practice and deciding which product should be included in their offer, the most important basic question veterinarians should answer is: What is the aim of veterinary practice? Possible answers could be low costs, to be an innovator and offer a hi-tech service, or be in the middle of those two concepts with a "client friendly" strategy and a medium price. After defining this target, the management of the practice can easily decide which products and services should be offered.

When speaking about pricing strategies, a basic rule is that all calculations should rely on the cost price. There are four strategies used in veterinary practice (Ackermann, 2007):

1) Competitive prices - used for products that are widely available in the market and can be bought, like vaccines. It is highly important that these prices are kept at the same level with competition in order not to lose the clients.

2) Value-based pricing -implicates prices of products and services, which are exclusive first-class services associated with high level of veterinarian expertise required. A highly qualified personnel employed at the veterinary clinic is a prerequisite for setting high prices and making extra profit.

3) Cost-based pricing - this is the mostly used method as it is simple to calculate. A selling price is formed when selling margin is added to the cost price. Development of internet has offered to clients an easy access to the wide range of products thus reducing the retail possibilities at veterinary clinics. In this respect, veterinary clinic should only purchase products that require professional assistance or advice of a veterinarian. Furthermore, the clients have impression to receive better product with professional service from a veterinary clinic then from the internet.

4) Variable cost pricing - this strategy is highly effective in covering all expenses related to product or service offered. If the clinic is capable of increasing the range of products and services without increasing the labor or space needed, this method is very effective. 
Promotion encompasses communication with animals' owners using personal or non-personal techniques about the range of products and services offered, as well as about the characteristics of your veterinary practice (Savić et.al.2010). The main objective of the promotion is to increase awareness of the quality of your veterinary practice among clients. When it comes to veterinary medicine, public relations is the most important way of promotion- appearance on TV or radio, publishing articles, organizing "open-door days" etc. Moreover, online advertising (web site, log), advertisements in professional literature, yellow pages and various public programs are also of particular importance. Although all aforementioned actions are very effective, the research has shown that the majority of clients choose a certain practice mainly based on the reference and experience of other animal owners. Thus, the best way of promotion of a veterinary practice is to provide always the best possible service (Molhoek and Edenburg, 2009).

The location of a veterinary practice or clinic is important and that gives the first impression to the client about the practice (Stowe, 1999). Location is not as important as in some other business branches but it would surely help if the practice was on a good spot with an easy and fast access and a big enough parking space. The entire practice space should be clean, light and odor-free, since it indirectly informs the client about the high quality service that he / she will receive for their money. The waiting room is where the first impressions of the clients are formed, which than determines their expectations regarding the surgery room. Things like professional magazines, photos of the clients with their pets on the walls, flowers etc. are very effective. Furthermore, taking consideration of clients' needs while waiting is very important, thus it is necessary to provide the waiting room with phone, toilet, toys for kids, coffee on the house, etc. All this increases the perception of client's importance and enables the creation of a long lasting relation with the client (Silk, 2006).

\section{Client relationship management}

Regardless of the reasons for practicing veterinary medicine (e.g. love for animals or other) it should be considered a business. Clients are the most important aspect of every business and it is necessary to focus on client relationships and to meet their needs (Međugorac, 2009). Establishing a client-oriented practice requires a well-organized teamwork, where all team members work collaboratively sharing the same philosophy. Client-oriented attitude pertains not only to veterinarians but also to the personnel working at the reception desk. Every member of the team should continuously strive to delight the client by offering the most remarkable service. Consistency is the most crucial part of the interaction with the client. It is accomplished through creating and applying appropriate workplace protocols and procedures. Such protocols precisely define everyone's particular 
duties and responsibilities within the company. The first impression of the client is very important, $65 \%$ of the picture about the practice comes from the interaction with the personnel and even $68 \%$ of clients leave the practice because of the indifferent relation of the employees (Ackermann, 2007). The first step towards successful serving of the client is to get to know him/her as well as possible, learn and meet the wishes and needs of the client and his pet. Therefore, the main question is how to get to know the client? Firstly, it is necessary to identify the groups of clients, i.e. service consumers. This strategy is called market segmentation. Veterinary medicine services imply many kinds of different clients. One of the ways to get to know clients better is to give them a questionnaire about: who they are, how close they live, their incomes, which animals they have, etc. Furthermore, it is necessary to analyze which clients bring most money to the practice and pay them some extra attention. According to Pareto's law, $80 \%$ of the practice income is achieved from $20 \%$ of the clients. These clients do not come to particular veterinary practice because of the prices but rather because of good service quality so the quality must be maintained at the highest level. Meeting the needs of such clients (making appointments, house visits, feed and medicine delivery, etc) whenever it is possible is highly recommendable. Of course, it does not mean that other clients are not important, but these deserve some kind of a bonus for their loyalty. Segmentation strategy enables offering specialized veterinary services to specific clients when justified. This primarily relates to growing number of clients having exotic animals as pets (Ackermann, 2002).

Dr. Lowell Ackerman speaks of six "C" management relations with the client in veterinary practice (Ackerman, 2007):

1) Consistency: clients want a unique attitude about the way of treatment, not different opinions from different veterinarians at the clinic

2) Compassion: clients are attached to their animals and they expect that the veterinarians show love and compassion for the animals

3) Client service: clients like to be treated as important for the veterinary organization or they would leave, which is very expensive - it is more expensive to attract a new client then to keep an old one, and old clients are usually more profitable then the new ones

4) Convenience: in modern society, people have less and less time and so it is necessary to meet the clients' demands, and they will reward that. It is necessary to make it easy for the clients.

5) Competence: clients cannot estimate the expertise of a veterinarian because the lack of professional knowledge. It is necessary to use every opportunity to suggest one's level of expertise (degree, license, rewards...).

6) Cost: no client ever wants to overpay the service, no matter how professional it is. They would rather go to the competition. It is very important to take care about the pricing policy and consider all the aspects. 


\title{
Conclusion
}

As in any other business areas, marketing in veterinary practice is getting increasingly important in relation to the other activities within the company. This is a result of considering veterinary practice a business as any other branch, sharing the same goals and problems in realization of these goals. In the light of current globalization, growing competition and expansion of innovative technologies associated with massive availability of information, a fight for every customer is the main task and the prerequisite for the survival of each particular veterinary practice. Understanding that the client is its most valuable asset and a reason for the existence of veterinary practice should be the milestone of their working policy, and clients should be treated accordingly. Clients experience in communication with veterinary practice should be simple, professional, pleasant and effective. If a veterinary company fulfills all the aforementioned conditions, it is on a good way of creating mutually profitable and long lasting relationship with its clients that ensures its survival in the market.

\section{Acknowledgment}

Paper is financed by the Ministry of Education, Science and Technological Development of the Republic of Serbia, project No. III- 43007.

\section{Značaj i primena marketinga u veterinarskoj maloj praksi}

\author{
V. Vidić, S.Savić, B.Vidić, Ž.Grgić
}

\section{Rezime}

Marketing ima dva cilja. Prvi je, da privuče nove klijente naglašavajući potencijalnu vrednost proizvioda ili usluge koji se nude. Drugi, zadržati postojeće klijente tako što će oni biti permanentno zadovoljni uslugom ili proizvodom, tako što ćemo prevazilaziti njihova očekivanja i uvek im pružati više.

Za razliku od SAD gde je najviše urađeno kako u teoriji tako i praksi na implementaciji marketinga u veterinarskoj delatnosti i razvoju svesti kod veterinara pre svega o prednostima prihvatanja marketing filozofije, u Srbiji se ova tema nije značajnije izučavala. Cilj marketinga u veterinarskoj delatnosti je da izgradi uzajamno profitabilne dugoročne odnose sa klijentima, a ne samo da proda određeni proizvod ili uslugu. Bez obzira na lične razloge 
pojedinaca da se odluče za bavljenje veterinarskom delatnošću, a pre svega poslovima male prakse, potrebno je ovu delatnost posmatraju kao i svaki drugi posao, koja treba da obezbedi profit. Da bi se ovo postiglo, neophodno je usvojiti marketinški način razmišljanja i upravljati marketingom.

Temeljni instrumenati marketinga su proizvod, cena, promocija i mesto koji čine takozvani marketing miks koji se može primeniti i na veterinarsku praksu. U veterini proizvod se odnosi ili na potrošne stavke, kao što su lekovi ili hrana, ili na usluge veterinara. Kod utvrđivanja cene, polazna osnova mora biti cena koštanja, na koju se dodaje marža koja zavisi od vrste proizvoda i usluge koja se nudi. Promocija predstavlja komunikaciju sa vlasnicima životinja o proizvodima $\mathrm{i}$ uslugama koje se nude $\mathrm{i}$ o karakteristikama klinike ili ambulante. Za razliku od drugih delatnosti, lokacije veterinarske organizacije nema toliku važnost, ali svakako mora biti u funkciji dobrog poslovanja sa vlasnikom životinja. Celokupno iskustvo klijenta od ulaska u kliniku ili ambulantu do izlaska mora biti profesionalno, ugodno i efikasno. Samo ako se ovo ostvari moguće je biti konkurentan ili čak naplatiti više za superiornu uslugu.

\section{References}

ACKERMAN J.L. (2002): Business Basic for Veterinarians, ASJA, Lincoln, New York.

ACKERMAN J.L. (2007): Blackwell's Five Minute Veterinary Practice Management Consult, Blackwell Publishing, USA.

BOBOŠ S., RADINOVIĆ M., VIDIĆ B., PAJIĆ M., VIDIĆ V., GALFI A. (2013): Mastitis therapy - direct and indirect costs. Biotechnology in Animal Husbandry, ISSN 1450-9156, 29, 2, 269-275.

KOTLER P. (2003): Marketing insights from A to Z: 80 Concepts every manager needs to know. John Waley \& Sons, New Jersey.

KOTLER P. (1988): Upravljanje marketingom 1. Zagreb, Informator.

KOTLER P. (2008): Upravljanje marketingom. Zagreb.

MEĐUGORAC S. (2009): Marketing veterinarskih usluga, Magistarski rad, Ekonomski fakultet, Zagreb.

MOLHOEK A.W.I, EDENBURG N. (2009): The effectiveness of marketing concepts in veterinary practices, Tijdsch.voor Diergk., 134, 1, 4-10.

MORE K., POREEK N. (2010): Marketing: the basics, Niketh Pareek, Routledge, New York.

PRIDE M.W., FERELL O.C. (2010): Marketing, South-Western cengage learning, Mason, USA. 
SAVIĆ S., VIDIĆ B., LAZIĆ S., LAKO B., POTKONJAK A., LEPŠANOVIĆ Z. (2010): Borrelia burgdorferi in ticks and dogs in the province of Vojvodina, Serbia.Parasite, ISSN 1252-607X, 17,357-361.

SILK J.A. (2006): What is Marketing? Harvard Business school Publishing Corporation.

STOWE J.D. (1999): Brand loyalty and veterinary practice marketing. Can.Vet.J.,40, 816-81 .

TADIĆ M. (2011): Marketing veterinarskih usluga. Vet. Stanica, 45, 5, 471- 480.

VASILJEV S. (2005): Marketing, četvrto izdanje, Prometej, Novi Sad.

VIDIĆ B, SAVIĆ-JEVĐENIĆ S., GRGIĆ Ž., BUGARSKI D., MALJKOVIĆ M. (2007): Infectious abortion in sheep. Biotechnology in animal husbandry. - ISSN 1450-9156. -. 23, 5-6, 383-389.

VIDIĆ B., SAVIĆ S., PRICA N. (2011b): Paratuberculosis in cattle - the outspread, diagnostics and control. New Perspectives and Callenges of Sustainable Livestock Production.Book 1, 3rd International Congress, Belgrade, 5-7 October 2011, Beograd, Institute for Animal Husbandry, 335-344.

VIDIĆ V. (2012a): Marketing usluga savremene veterinarske prakse. Arhiv veterinarske medicine, ISSN 1820-9955, 5, 2,.67-76,.

VIDIĆ V. (2012b): Marketing in veterinary. Proceedings, Second International epizootiology Symposium XIV Serbian epizootiology days, April 18-21, 2012, Belgrade, Sekcija za zoonoze, ISBN 978-86-83115-20-4, 271-277.

VIDIĆ B., SAVIĆ S., VIDIĆ V., JOVIČIN M., PRICA N. (2013): Economic impact of paratuberculosis on milk production. Biotechnology in Animal Husbandry, ISSN 1450-9156, 29, 2, 183-191.

www.marketing.com

Received 11 September 2013; accepted for publication 20 December 2013 